
COELHO, FC. 2020. Distinctness, uniformity and stability and GT biplot tests for the selection of snap bean lines. Horticultura Brasileira 38: $370-377$. Doi: http://dx.doi.org/10.1590/s0102-053620200405

\title{
Distinctness, uniformity and stability and GT biplot tests for the selection of snap bean lines
}

\author{
Camila QSS de Sant'Anna ${ }^{1} \mathbb{D}$; Tâmara Rebecca A de Oliveira ${ }^{1} \mathbb{D}$; Geraldo de A Gravina ${ }^{1} \mathbb{D}$; Derivaldo $P$ \\ da Cruz ${ }^{1} \mathbb{D}$; Andrea BS Gomes ${ }^{1} \mathbb{D}$; Rogério F Daher ${ }^{1} \mathbb{D}$; Marcelo Vivas ${ }^{1} \mathbb{D}$; Gustavo Hugo F de Oliveira ${ }^{2} \mathbb{D}$; \\ Geovana C Entringer ${ }^{1} \mathbb{D}$; Fábio C Coelho ${ }^{1 \mathbb{D}}$
}

${ }^{1}$ Universidade Estadual do Norte Fluminense Darcy Ribeiro (UENF), Campos dos Goytacazes-RJ, Brasil; mylacqs@gmail.com; tamara rebecca@hotmail.com; gravina@uenf.br; deri.engineer@gmail.com; andreabarross@outlook.com; rogdaher@uenf.br; mrclvivas@hotmail. com; geovanaentringer@gmail.com; fabiocoelhouenf@gmail.com; ${ }^{2}$ Universidade Federal de Sergipe (UFS), São Cristóvão-SE, Brasil; gustavo.melhorista@gmail.com

\begin{abstract}
The lack of records about snap bean cultivars is one of the obstacles that has led to a yield gap and low prominence of the crop. This work aimed at indicating snap bean lines obtained by the Breeding Program of the Universidade Estadual do Norte Fluminense (UENF) to assess their performance and to apply for a certificate of plant variety protection. The study was managed using a randomized block design with three replicates in a greenhouse at the Research Support Unit of the UENF. Nine candidate lines were compared to the commercial cultivar "Topseed Blue Line" in accordance with 56 descriptors set by the National Plant Variety Rights. All lines presented themselves as homogeneous. The L31 line provided a total of 30 different descriptors of the commercial cultivar. For the quantitative data added to the Distinctness, Uniformity and Stability, (DUS) tests, the analysis of variance was performed and the GT biplot generated by the R software. Variability was noticed among the genotypes for all assessed traits, excepting days until germination and seed thickness. The lines that showed the best mean performance were L6, L7, L10, L11, and L13. Among those, the L6 and L11 lines provided higher stability.
\end{abstract}

Keywords: Phaseolus vulgaris, multicategorical descriptors, multivariate analysis, new technological products.

\section{RESUMO}

Testes de Distinguibilidade, Homogeneidade e Estabilidade e GT biplot na seleção de linhagens de feijão-vagem

A falta de registros sobre as cultivares de feijão-vagem é um dos obstáculos que levaram à lacuna na produtividade e baixo destaque da cultura. Este trabalho teve como objetivo indicar as linhagens de feijão-vagem obtidas pelo Programa de Melhoramento da Universidade Estadual do Norte Fluminense (UENF) para avaliar seu desempenho quanto ao certificado de proteção de cultivares. $\mathrm{O}$ estudo foi conduzido usando delineamento em blocos casualizados com três repetições em casa de vegetação da Unidade de Apoio à Pesquisa da UENF. Nove linhas candidatas foram comparadas com a cultivar comercial "Topseed Blue Line", de acordo com 56 descritores estabelecidos pelos National Plant Variety Rights. Todas as linhas se apresentaram homogêneas. A linha L31 forneceu um total de 30 descritores diferentes da cultivar comercial. Para os dados quantitativos adicionados aos testes Distinguibilidade, Homogeneidade e Estabilidade (DHE), foi realizada a análise de variância e o biplot GT gerado pelo software R. Foi observada variabilidade entre os genótipos para todas as características avaliadas, exceto dias até germinação e espessura das sementes. As linhagens que apresentaram melhor desempenho médio foram L6, L7, L10, L11 e L13. Entre essas, as linhas L6 e L11 proporcionaram maior estabilidade.

Palavras-chave: Phaseolus vulgaris, descritores multicategóricos, análises multivariadas, novos produtos tecnológicos.

\section{Received on February 28, 2020; accepted on October 1, 2020}

$\mathrm{T}$ he snap bean is an oleraceous plant of high economic importance mainly for small producers. Despite being a less expressive crop when compared to commodities, it is well accepted and consumed in Brazil (Brito et al., 2013).

Its low prominence combined with scarce information and low quantity of publications about this crop hinder the breeding process, which goal is to obtain more productive and adapted cultivars for different regions. As such, supporting researches in order that breeding programs can obtain new lines of snap bean and apply for the plant breeders' rights is of utmost importance.

Plant breeders' rights were granted by the plant varieties protection law $\mathrm{n}$. 9.456 of April 1997, which provides intellectual property protection in the breeding field, conceding the breeder the right to receive royalties within a set time period, in exchange for the 
commercial exploitation of the new cultivar (Araújo, 2010). Requirements are recommended in order that a new cultivar has its effective protection. For that it is necessary to carry out Distinctness, Uniformity and Stability (DUS) tests under the criteria of the National Plant Variety Protection (PVP), an organ belonging to the Ministry of Agriculture, Livestock and Food Supply (MAPA), responsible for the issuance of the plant breeding certificate (Machado, 2011; UPOV, 2016).

DUS experiments are conducted in only one location, for, at minimum, two similar cultivation years (Machado, 2011). They are founded in 56 descriptors, published in the Official Federal Gazette, based on the species (Brasil, 2015) and intend to investigate cultivars able to the effective intellectual protection.

The application of quantitative variables together with the DUS tests, on the basis of qualitative traits, allows selecting more productive lines with a higher number of traits of agronomic interest.

Among the multivariate methodologies, the genotype $\mathrm{x}$ trait biplot (GT biplot) is an effective analysis which enables an accurate assessment of the selection of stable genotypes, with more significant traits, for selections within the breeding program (Mohammadi \& Amri, 2013; Oliveira et al., 2018). Moreover, Gower distance allowed examine qualitative and quantitive data; in terms of multivariate cluster this proceed is the most used. (Silva et al., 2015; Gomes et al., 2019).

In this way, the current research focused on indicating snap bean lines obtained by the Breeding Program of UENF according to the tests for the plant variety protection application and the selection of the ones that present the best average performance.

\section{MATERIAL AND METHODS}

\section{Plant material}

The research used nine candidate lines of snap beans of indeterminate habit, from the snap bean Breeding Program of the Universidade Estadual do Norte Fluminense (UENF), and a commercial genotype of the Topseed Blue Line of pole snap bean (Table 1).

The superior lines were obtained by the SSD (Single Seed Descent) method, corresponding to $\mathrm{F}_{9}$ and $\mathrm{F}_{10}$ generations (Figure 1). The genitors that originated the crosses were selected according to their yield traits, high pod number per plant, long pod length, low fiber content, and early growth (Abreu et al., 2004).

\section{Location and experimental design}

The experiment was performed in a greenhouse located at the Research Support Unit (RSP) of UENF ( $\left.21^{\circ} 45^{\prime} 44^{\prime \prime} \mathrm{S}, 41^{\circ} 17^{\prime} 15^{\prime \prime} \mathrm{W}\right)$, composed of two experiments over the periods from April to August 2016 and 2017.

The randomized block experimental design was used with three replicates and three plants per plot, reaching 90 plants. The Official Journal n. 133 of July 15, 2015 states that to assess protected plant varieties, each test should have, at least, 60 plants for cultivars with indeterminate growth habit, divided into two or more replicates (Brasil, 2015).

\section{Experimental conduction}

Seeds were sown in $5 \mathrm{~L}$ pot, $1 \times 0.5$ m space, with Basaplant ${ }^{\circledR}$ Hortaliças commercial substrate, composed of pinus bark, peat, coal, vermiculite, initial fertilization with NPK in formulation 4-14-8, $3 \mathrm{~g} /$ pot at 35 and 50 days. The maintenance fertilization with urea, simple superphosphate, and potassium chloride, and the phytosanitary treatments were carried out as recommended for the crop, as well as the other phytosanitary treatments performed during the whole crop (Filgueira, 2013). The irrigation system used in the experiments was the microsprinkler one.

\section{Evaluated traits}

Regarding the 56 descriptors proposed for the Phaseolus vulgaris species, 52 of them were evaluated for the indeterminate growth habit (type IV), grouped in accordance with the plant development stage (seedling, flowering, pod and seed yield) and based on direct observations, in which each trait held a grade relative to the evaluation.

The assessed quantitative traits were germination period [(GP), total day count from planting to germination], flowering [(FLOW), total day count from planting to flowering], yield [(YIE), total day count from planting to pod yield], pod length [(PL), measured in centimeters $(\mathrm{cm})$ using a ruler], pod width [(PW), measured in millimeters $(\mathrm{mm})$ at the central position of the dry pod, using a digital caliper], pod thickness [(PT), measured in millimeters $(\mathrm{mm})$ at the central position of the dry pod, using a digital caliper], seed length $[(\mathrm{SL})$, measured in millimeters $(\mathrm{mm})$ at the central position of the dry pod, using a digital caliper], seed width [(SW), measured in millimeters $(\mathrm{mm})$ at the central position of the dry pod, using a digital caliper], seed thickness [(ST), measured in millimeters $(\mathrm{mm})$ at the central position of the dry pod, using a digital caliper], size of the flower bracts $[(\mathrm{FB})$, measured in millimeters $(\mathrm{mm})$, using a digital caliper], mean number of seeds per pod [(SP), mean quantity of seeds per pod in each plant].

\section{Data evaluation}

The lines were compared between themselves and the commercial cultivar Topseed Blue Line (control). For the submission of the technical-descriptive report, which is needed to apply for a certificate of plant variety protection, a comparison of only one control plant in each report is required, but not excluding the possibility to use several treatments-control in a DUS test (Brasil, 2015).

The qualitative data were assessed by the descriptive analysis method, obtaining then the mode, which is the most frequent value within a data set, of the traits attributed to each genotype.

The analysis of the principal components (PCs) was performed to study the quantitative data, in which the first two PCs were applied to group the genotypes and generate the biplots. This way, the PC1 was used in the horizontal axis, and the $\mathrm{PC} 2$, in the vertical one. Besides, Gower distance analysis for quantitative and qualitative data were 
considered.

The analyses of variance, analyses of principal components, the biplot graphics and Gower distance were obtained by means of the $\mathrm{R}$ software (Wickham, 2016).

\section{RESULTS AND DISCUSSION}

\section{Qualitative descriptors}

No differences were reported between the candidate lines and the commercial genotype in 14 of the 52 descriptors verified. These descriptors were as follows: growth habit and plant size, leaf roughness, central leaflet size, apex shape and length of the terminal leaflet, primary color and color intensity of the pod, presence of ventral suture line, position of the apical tooth and pod surface texture, number of colors, secondary color, and distribution of the secondary color in the seeds.

The similarities observed for growth habit and plant size are confirmed using selected lines with the goal of attending to the indeterminate growth habit and pole size (Almeida et al., 2014). In Brazil, the main recommended cultivars are the ones of indeterminate growth, which achieve greater yields, although its disadvantage of a greater demand for labor, given the need for tutoring (Francelino et al., 2011; Filgueira, 2013).

The traits related to the pod were selected concerning the pattern of the Brazilian consumer market. According to that they have green color and straight texture as the main standard traits demanded (CEAGESP, 2015), then, justifying the similarity of these traits.

The descriptors for size and shape of the leaf, and seed color, are morphological aspects intrinsic to the snap bean variety. It is worth mentioning the low notoriety, even relevant, of these descriptors in the selection processes for the snap bean crop (Abreu et al., 2004).

The homogeneity of the descriptors applied for both cycles could be verified. From the crop of 90 plants, only one (L10 genotype) was atypical in the second test, suggesting there was some alteration caused by abiotic factors, once the other plants were stable, which also allowed concluding their level of homozygosis, considered high. The Official Journal n. 133 of July 15, 2015 established the pattern of $1 \%$ acceptance probability for atypical plants (Brasil, 2015).

In general, studies regarding the plant variety protection propose that homogeneous plants tend to be stable (Santos \& Machado, 2011), allowing them to meet the requirements for the application for protection.

It was possible to verify a distinction of, at least, 15 (L11) and, at most, 30 descriptors (L31) of all candidate lines tested concerning the commercial genotype (control) (Table 2 ) and reference intervals, according to Sant'Anna (2019). Pimenta et al. (2016) pointed out two Capsicum annuum var. annиит genotypes suitable for protection on the basis of 13 and 16 descriptors, out of 48 recommended for the species, which proved to be different from the control.

In accordance with Machado (2011), in the directives developed for the Distinctness, Uniformity and Stability (DUS) tests, it is established that a descriptor is considered suitable in a DUS test when it allows verifying differentiation among the candidate genotypes. Within this context, the distinction between the candidate lines themselves was noticed in, at least, 7 (L6 and L7) and, at most, 31 descriptors (L10 and L31), out of the 52 tested for the snap bean crop. The small differentiation between the L6 and L7 lines is that they are from the same parents UENF (1442 x 1429).

Some descriptors should be highlighted in terms of relevance in the distinction between the candidate lines, and in their significance for the farmer and the consumer market, being them: flowering and total cycles, speed and development cycle of the pole habit, and traits related to the pod (length, width, thickness, and shape of the transverse section), which allow inferring the type of group in which the pod belongs (pole or butter), and the quality (degree of tenderness and good size that meets the market acceptance together with greater production efficiency) (Almeida et al., 2014).

Explanations on the flowering and total cycles (harvest) are of great relevance. During a breeding program, obtaining hybrids by the hybridization technique demands knowledge about the flowering synchrony between the genotypes used, as this confirmation allows for a good planning and success in the implementation of the technique and, consequently, in obtaining hybrids (Silva et al., 2017).

Plants with earlier flowering will tend to an early yield, thus to a smaller cycle, being an advantage when it comes

Table 1. Identification of candidate lines, accession number in the UENF germplasm collection, genitors and information about mean yield and mean of pod number per plant, collected during VCU (Value for Cultivation and Use) tests performed by Araújo et al. (2015). Campos dos Goytacazes, UENF, 2016/2017.

\begin{tabular}{|c|c|c|c|c|}
\hline Lines & $\begin{array}{c}\text { UENF } \\
\text { Number }\end{array}$ & Genitors & $\begin{array}{l}\text { Productivity } \\
\left(\mathrm{t} \mathrm{ha}^{-1}\right)\end{array}$ & $\begin{array}{c}\text { Pod } \\
\text { (number/plant) }\end{array}$ \\
\hline L31 & $15-23-113$ & UENF (1448x 1445) & 26.09 & 65.49 \\
\hline L21 & $14-4-24$ & UENF (1448x 1442) & 25.69 & 66.31 \\
\hline L20 & $9-27-97$ & UENF (1448x 1429) & 29.82 & 74.31 \\
\hline L13 & $7-20-50$ & UENF (1442 x 1429) & 31.71 & 51.83 \\
\hline L11 & $7-12-42$ & UENF (1442 x 1429) & 28.18 & 56.87 \\
\hline L10 & $7-10-10$ & UENF (1442 x 1429) & 28.38 & 58.00 \\
\hline L7 & $7-6-6$ & UENF (1442 x 1429) & 32.24 & 80.89 \\
\hline L6 & $7-5-5$ & UENF (1442 x 1429) & 33.26 & 73.75 \\
\hline L4 & $7-3-3$ & UENF (1442 x 1429) & 27.31 & 52.20 \\
\hline L3 & $\begin{array}{l}\text { Top Seed } \\
\text { Blue Line }\end{array}$ & 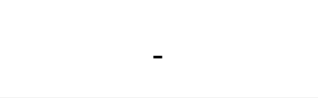 & 28.37 & 60.58 \\
\hline
\end{tabular}


Table 2. Outline of the main distinctive morphological descriptors between the Topseed Blue Line cultivar and the candidate lines to the plant variety protection application. Campos dos Goytacazes, UENF, 2016/2017.

\begin{tabular}{|c|c|c|c|c|c|c|c|c|c|c|}
\hline \multirow[t]{2}{*}{ Descriptors } & \multirow{2}{*}{$\begin{array}{c}\text { Comercial } \\
\text { genotype }\end{array}$} & \multicolumn{9}{|c|}{$\begin{array}{l}\text { Differences found in candidate strains to cultivar protection } \\
\text { in the } 1^{\text {st }} \text { and } 2^{\text {nd }} \text { test }\end{array}$} \\
\hline & & $\mathbf{L 4}$ & L6 & L7 & L10 & L11 & L13 & L20 & L21 & L31 \\
\hline $\begin{array}{l}\text { Seedling anthocyanin } \\
\text { pigmentation in the } \\
\text { hypocotyl }\end{array}$ & Absent & & & & & & & Present & & \\
\hline $\begin{array}{l}\text { Seedling pigmentation } \\
\text { intensity }\end{array}$ & - & & & & & & & $\begin{array}{l}\text { Weak to } \\
\text { median }\end{array}$ & & \\
\hline Plant shape & Rectangular & & & & & & & & Pyramid & Pyramid \\
\hline $\begin{array}{l}\text { Plant cycle until the } \\
\text { development of the } \\
\text { climbing habit }\end{array}$ & Median & & Early & & Late & & Early & & Late & \\
\hline $\begin{array}{l}\text { Plant velocity to develop } \\
\text { the climbing habit }\end{array}$ & Median & & Fast & & Low & & Fast & & Slow & \\
\hline $\begin{array}{l}\text { Intensity of the green } \\
\text { shade on leaf }\end{array}$ & $\begin{array}{l}\text { Light to } \\
\text { median }\end{array}$ & $\begin{array}{l}\text { Median } \\
\text { to dark }\end{array}$ & & & & & & & & $\begin{array}{l}\text { Median } \\
\text { to dark }\end{array}$ \\
\hline Bract size of flower & Median & & Big & Big & Big & Big & Big & Big & Big & Big \\
\hline Banner color of flower & White & $\begin{array}{l}\text { Pink } \\
\text { white }\end{array}$ & & & $\begin{array}{l}\text { Pinkish } \\
\text { white }\end{array}$ & & & Violet & & \\
\hline Wing color of flower & White & & & & & & & Violet & & \\
\hline $\begin{array}{l}\text { Pod length (excluding } \\
\text { the beak) }\end{array}$ & Median & & & & Long & & Long & & & Short \\
\hline Pod width & Narrow & & Median & Median & Median & Median & Median & Median & Median & Median \\
\hline Pod thickness & Thick & Median & Median & Median & & Thin & Median & Thin & Thin & Thin \\
\hline Pod cross section shape & Circular & Elliptic & Elliptic & Elliptic & & Elliptic & Elliptic & Elliptic & Elliptic & Elliptic \\
\hline $\begin{array}{l}\text { Pod thickness/width } \\
\text { ratio }\end{array}$ & Large & Median & Median & Median & & Median & Median & Small & Small & Small \\
\hline $\begin{array}{l}\text { Presence of secondary } \\
\text { color }\end{array}$ & Absent & Present & & & & & Present & Present & Present & Present \\
\hline Secondary color of pod & & Purple & & & & & Purple & Purple & Purple & Purple \\
\hline $\begin{array}{l}\text { Density of spots on the } \\
\text { secondary color of pod }\end{array}$ & & Median & & & & & Light & Thick & Light & Light \\
\hline $\begin{array}{l}\text { Degree of curvature of } \\
\text { pod }\end{array}$ & & L4 & L6 & L10 & L13 & $\mathrm{L} 21$ & L31 & & & \\
\hline Curvature shape of pod & & L6 & $\mathrm{L} 7$ & L10 & $\mathrm{L} 20$ & L31 & & & & \\
\hline $\begin{array}{l}\text { Shape of the distal part } \\
\text { of pod (excluding the } \\
\text { apical tooth) }\end{array}$ & & L6 & L7 & L11 & L13 & L20 & $\mathrm{L} 21$ & L31 & & \\
\hline $\begin{array}{l}\text { Length of the apical } \\
\text { tooth of pod }\end{array}$ & & L6 & L10 & L13 & L20 & L31 & & & & \\
\hline $\begin{array}{l}\text { Curvature of the apical } \\
\text { tooth of pod }\end{array}$ & & L4 & L6 & L7 & L10 & L11 & L13 & L20 & $\mathrm{L} 21$ & \\
\hline $\begin{array}{l}\text { Position of the apical } \\
\text { tooth of pod }\end{array}$ & & No diff. & & & & & & & & \\
\hline Surface texture of pod & & No diff. & & & & & & & & \\
\hline $\begin{array}{l}\text { Constrictions of pod } \\
\text { (dry pod) }\end{array}$ & & L4 & L6 & L7 & L11 & L13 & L20 & L21 & L31 & \\
\hline
\end{tabular}


Table 2. continuation

\begin{tabular}{|c|c|c|c|c|c|c|c|c|c|}
\hline \multirow[t]{2}{*}{ Descriptors } & \multicolumn{9}{|c|}{$\begin{array}{l}\text { Differences found in candidate strains to cultivar protection } \\
\text { in the } 1^{\text {st }} \text { and } 2^{\text {nd }} \text { test }\end{array}$} \\
\hline & $\mathbf{L 4}$ & L6 & L7 & L10 & L11 & L13 & L20 & $\mathbf{L 2 1}$ & L31 \\
\hline Seed weight & $\mathrm{L} 4$ & L6 & $\mathrm{L} 7$ & L10 & L13 & L20 & L21 & & \\
\hline $\begin{array}{l}\text { Shape of the longitudinal } \\
\text { section of seed }\end{array}$ & L6 & L7 & L11 & L13 & L20 & $\mathrm{L} 21$ & L31 & & \\
\hline $\begin{array}{l}\text { Curve degree of the } \\
\text { reniform shape of seed }\end{array}$ & L6 & L7 & L10 & L13 & L20 & $\mathrm{L} 21$ & L31 & & \\
\hline $\begin{array}{l}\text { Shape in cross section } \\
\text { of seed }\end{array}$ & L31 & & & & & & & & \\
\hline $\begin{array}{l}\text { Width in cross section } \\
\text { of seed }\end{array}$ & L13 & L31 & & & & & & & \\
\hline Seed length & L6 & L7 & L10 & L13 & L20 & & & & \\
\hline Seed length/width relation & L6 & L7 & L20 & L21 & L31 & & & & \\
\hline $\begin{array}{l}\text { Seed thickness/width } \\
\text { relation }\end{array}$ & L11 & L20 & L21 & L31 & & & & & \\
\hline Number of colors of seed & No diff. & & & & & & & & \\
\hline Principal color of seed & L4 & L6 & $\mathrm{L7}$ & L10 & L11 & L13 & L20 & $\mathrm{L} 21$ & L31 \\
\hline Secondary color of seed & No diff. & & & & & & & & \\
\hline $\begin{array}{l}\text { Distribution of the } \\
\text { secondary color of seed }\end{array}$ & No diff. & & & & & & & & \\
\hline Seed venation & $\mathrm{L} 4$ & & & & & & & & \\
\hline Seed brightness & $\mathrm{L} 4$ & L6 & L7 & L10 & L11 & L13 & L20 & L21 & L31 \\
\hline $\begin{array}{l}\text { Color of the area around } \\
\text { the thread of seed }\end{array}$ & L4 & L6 & L7 & $\mathrm{L} 10$ & L11 & L13 & L21 & L31 & \\
\hline Halo color of seed & L4 & L6 & L7 & L10 & L11 & L13 & L20 & $\mathrm{L} 21$ & L31 \\
\hline Cycle until flowering & $\mathrm{L} 4$ & L11 & L13 & L20 & $\mathrm{L} 21$ & L31 & & & \\
\hline $\begin{array}{l}\text { Total cycle (from } \\
\text { emergence to harvest) }\end{array}$ & L4 & L13 & L20 & L21 & L31 & & & & \\
\hline
\end{tabular}

to reducing costs to the producer and promptly meeting the expectations of the consumer market. On the contrary, the use of later genotypes will make it possible to prolong the offer if there is market saturation, besides these alternatives, there is also the possibility of planting an early cultivar and another late one simultaneously to harvest scheduling (Andrade Júnior et al., 2002; Silva et al., 2017).

The L4, L20, and L31 lines, in contrast to the commercial line, were considered early for flowering (less than 30 days) and average for the total cycle, excluding L31, which had its total cycle as being early (44 days). The L13 and L21 lines showed average cycle for flowering and for total cycle. The Topseed Blue Line cultivar and the
L6, L7, L10, and L11 candidate lines presented a later flowering cycle (over 35 days), as a consequence, it was also a late total cycle, excepting the L11 line, which had an average flowering cycle.

Earlier studies on snap bean crop point out that the distinctions in the flowering and total days are very divergent, being directly connected to the cultivar under study and the growing period. Peixoto et al. (1997) stated that, in general, the harvests for the indeterminate growth habit start around 50 days after emergence. Oliveira et al. (2001), studying snap bean of indeterminate growth habit, considered lines above 43 days as late flowering, and below 38 days, as early. In the case of Vidal et al. (2007), when assessing the performance of bush snap bean in organic crop, for similar periods concerning this research, achieved the following results: maximum of 48 and minimum of 46 for flowering and 64 days for total cycle.

Among the traits relating to the pod, the length is quite relevant for its commercial quality, being a distinctive feature in the acceptance of the product by the consumer market (Almeida et al., 2014). Besides the length of the pod, descriptors, such as shape of section, width, and thickness determine the classification of the group in which the cultivar is inserted. In Brazil, the main commercial groups are the pole or butter type (Filgueira, 2013).

The pole-type pods have a round section, narrow width, and thickness. The Topseed Blue Line commercial 
Table 3. Overview of the analysis of variance for the traits germination period (GP); flowering (FLOW); yield days (YIE); pod length (PL); pod width (PW); pod thickness (PT); seed length (SL); seed width (SW); seed thickness (ST); size of the flower bracts (FB); mean number of seeds per pod (PS), assessed in nine lines of snap bean in two cultivation cycles. Campos dos Goytacazes, UENF, $2016 / 2017$.

\begin{tabular}{lccccccccccccc}
\hline \multirow{2}{*}{$\begin{array}{l}\text { Variation } \\
\text { source }\end{array}$} & $\begin{array}{c}\text { Degrees of } \\
\text { freedom }\end{array}$ & GP & FLOW & YIE & PL & PW & PT & SL & SW & ST & FB & PS \\
\hline Block (year) & 4 & 0.13 & 1.13 & 1.33 & 11.07 & 4.57 & 4.52 & 10.26 & 4.34 & 1.27 & 0.03 & 3.87 \\
Year (Y) & 1 & $11.27^{* *}$ & $340.82^{* *}$ & $501.13^{* *}$ & $101.04^{* *}$ & $93.37^{* *}$ & $42.74^{* *}$ & 7.70 & $49.69^{* *}$ & 0.01 & $299.80^{* *}$ & $22.82^{*}$ \\
Lines (L) & 9 & 0.14 & $59.41^{* *}$ & $53.73^{* *}$ & $35.26^{* *}$ & $19.83^{* *}$ & 2.11 & $23.38^{*}$ & $13.33^{*}$ & 3.02 & $2.89^{* *}$ & 6.82 \\
L x Y & 9 & 1.73 & $8.07^{* *}$ & 6.78 & 17.11 & 3.41 & 7.27 & 14.29 & $11.44^{*}$ & 3.62 & $2.89^{* *}$ & 5.26 \\
Residue & 36 & 0.11 & 4.84 & 4.86 & 11.38 & 6.11 & 4.25 & 9.67 & 4.93 & 3.62 & 0.03 & 4.70 \\
\hline Overall & & 4.60 & 35.05 & 38.38 & 15.93 & 10.36 & 6.12 & 13.66 & 7.48 & 4.99 & 4.11 & 7.28 \\
CV (\%) & & 7.67 & 6.68 & 5.97 & 22.22 & 22.80 & 36.02 & 23.82 & 33.34 & 43.55 & 24.17 & 30.12 \\
\hline
\end{tabular}

**Significant at $1 \%$ probability by the $\mathrm{F}$ test, * significant at $5 \%$ probability by the $\mathrm{F}$ test.

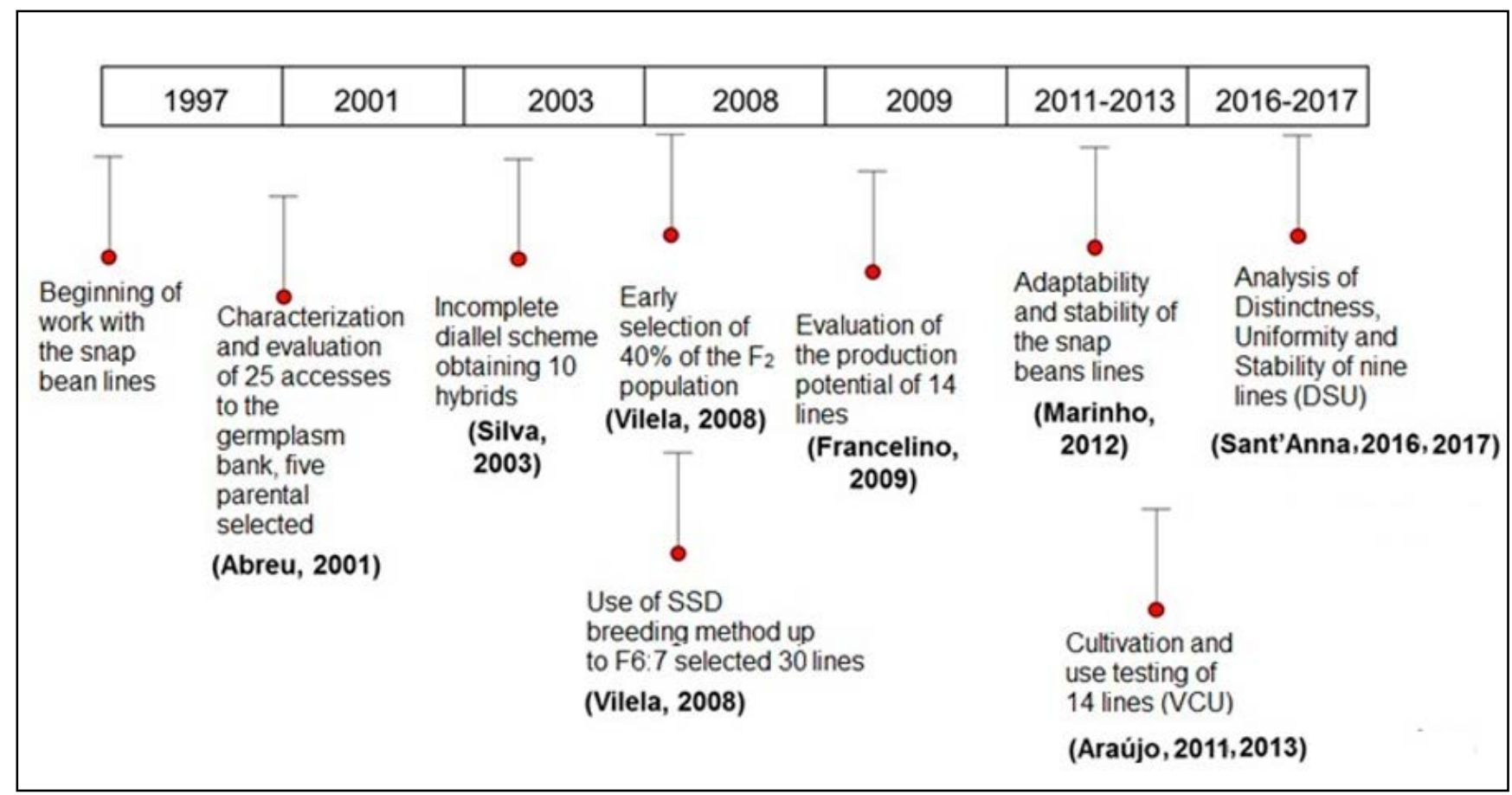

Figure 1. Timeline resuming the main works over 20 years of research on snap beans culture by the UENF Genetic Breeding Program. Campos dos Goytacazes, UENF, 2019.

cultivar and the L10 candidate line are in this group. The pole-type pods have a circular section, narrow width, and thickness. The Topseed Blue Line commercial cultivar and the L10 candidate line are in this group. The butter-type group comprised pods with elliptical section, long, and with thin to medium thickness. The following lines are also in this group: L4, L6, L7, L11, L13, L20, L21 and L31.

For the descriptors cycle and speed of plant development in terms of pole habit, the L6 and L13 stand out regarding early development and fast cycle, respectively (about 15 days). And the L7 and L20 lines, as a means in relation to both traits (around 20 days).

About the traits related to the pod, mainly its length, the L3 candidate line was highlighted for having long-length pods (average of $21 \mathrm{~cm}$ ) and the others, mean length (average value of $15 \mathrm{~cm}$ ). According to the width, thickness, and shape of the section traits, which allow inferring in which group they take part, all are in the butter group.

Another issue relating to the traits of the pod is based on its degree of curvature. The minimum quality standard, according to the classification rules set by the Companhia de Entrepostos e Armazéns Gerais de São Paulo (CEAGESP, 2015), for snap bean, considers that bent pods are classified as undesirable, with the producer discarding them before commercializing them. The L6, L7, L13, and L20 candidate lines were classified 


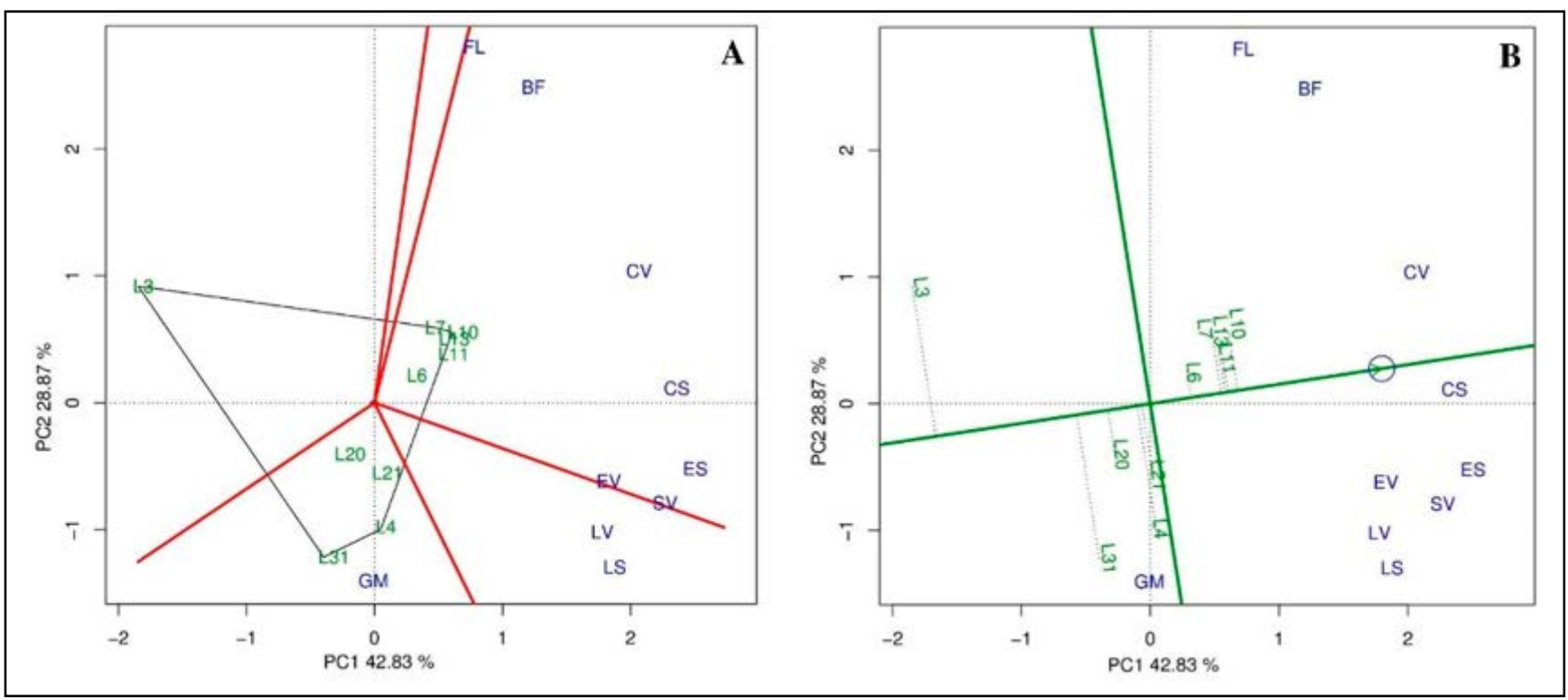

Figure 2. Biplot A) with projections of the variables flowering (FLOW); size of the flower bracts (FB); pod length (PL); seed length (SL); seed thickness (ST); pod thickness (PT); mean number of seeds per pod (PS); pod width (PW); seed width (SW); germination period (GP); B) means x stability, indicating the ranking of the nine snap bean lines according to the traits. Campos dos Goytacazes, UENF, 2019.

from low to medium, being, then, within the quality standard.

For the flowering and total cycle descriptors, the L13 and L20 lines were classified with a cycle from medium to early (approximately 30 days for flowering and less than 48 for the total cycle) and the L6 and L7 lines, as late (around 36 days for flowering and more than 52 for total cycle).

A relevant descriptor for the snap bean crop that is not included in the descriptors imposed by the SNPC/ MAPA, is the degree of tenderness or pod development stage, an important requirement for its quality, as the more tender the pod, the greater its commercial value. In accordance with the CEAGESP classification, the Topseed Blue Line cultivar, as well as the L6, L7, and L20 lines, received classification (2), that is to say, they were considered medium according to the degree of tenderness, and the L13 line was classified as (1) "ready", being desirable in terms of market.

\section{Analysis of variance, GT biplot and Gower distance}

The analysis of variance evidenced a substantial difference $(0.01 \leq \mathrm{P} \leq 0.05)$ among the lines for the (FLOW), (YIE), $(\mathrm{PL}),(\mathrm{PW}),(\mathrm{SL}),(\mathrm{SW})$, and $(\mathrm{FB})$ traits, proving the existence of genetic variability and providing arguments for a study on their performance for the selection of the superior ones (Table 3). The significance of line $\mathrm{x}$ years interaction demonstrates the differentiated performance of the lines over different years.

The biplot analysis revealed $71.70 \%$ of total variation among the lines (Figure 2A). As stated by Yang et al. (2009), at least $60 \%$ of the variation in the data should be explained by the PCs. Thus, it is suggested that the results found show efficiency and clearly demonstrate the traits under study.

The vectors from the biplot center $(0,0)$ enabled the graphic to be divided into four sectors. In this graphic, the lines verified in the vertices are further from the biplot origin, being named as of the best performance regarding the traits that originated the group. The first group, comprising the $\mathrm{FL}, \mathrm{BF}, \mathrm{CV}, \mathrm{CS}$, ES, EV and SV traits was constituted by the L6, L7, L10, L11, and L13 lines, with L10 and L13, located at the vertex of the biplot, having the best performance for these traits.

The second group, consisting of the LV and LS traits, did not allocate any of the lines that presented superiority for these traits. The third one, correspondent to GM, presented the L4 and L31 lines as more responsive, followed by the L 20 and L21. The Topseed Blue Line (L3) cultivar was allocated in the group 4, not

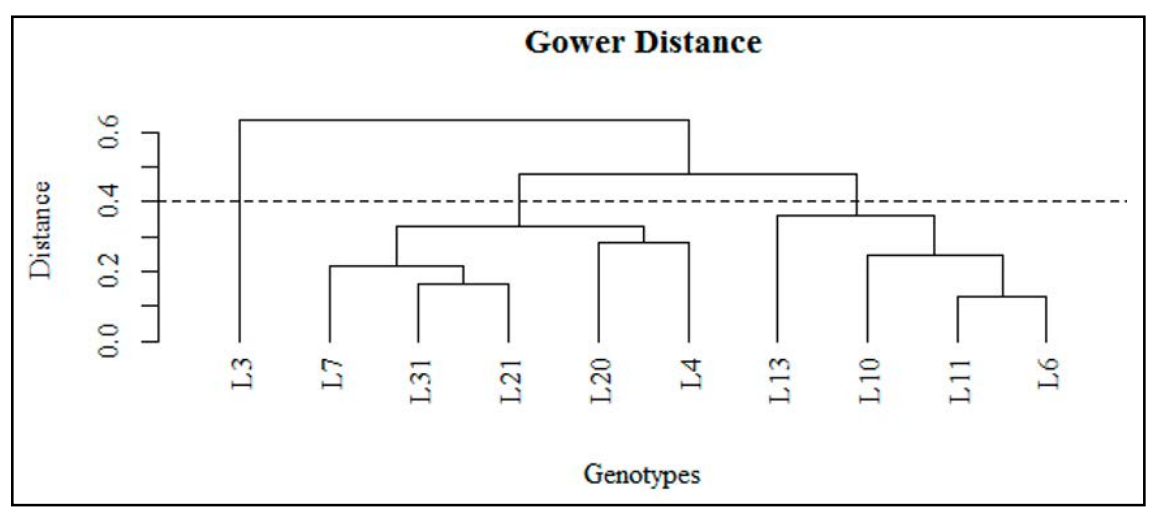

Figure 3. Dendrogram of 10 snap beans lines, based on Gower distance. Campos dos Goytacazes, UENF, 2019. 
presenting any prominent trait.

Oliveira et al. (2018) published that the number of seeds per pod indicates a high positive correlation with the pod and grain yield. Therefore, it is worth mentioning that the lines allocated in group 1 are probably the ones that present greater pod and grain yield.

The biplot that points out the representative capacity and the genotype distinction for the traits separates the genotypes that were below or above the overall mean, allowing the study of the stability of lines with respect to the traits under study (Figure 2B).

The circle formed in the horizontal line, which crosses the coordinate axis, represents the mean of the traits, thus, the closer the circle, the better the mean performance of the line. Then, L10, L11, L13, L7, and L6 lines, in this order, achieved the best overall mean and the Topseed Blue Line, the lowest overall mean.

Regarding stability, the distance between the genotypes and the horizontal line, delimited by the dotted lines, indicates greater or smaller stability according to the distance. This way, the closer the cultivar to the vector, the lower the stability observed, highlighting as the most stable lines, the L6 and the L11 and the most unstable ones, Topseed Blue Line, L4, and L31.

Three clusters were observed on dendrogram (Figure 3). Top Seed Blue Line (L3) cluster I; L4, L7, L20, L21 and L31 cluster II and L6, L10, L11 and L13 cluster III. These results are similar to GT biplot outputs, confirming the similarity among lines and yield potential for each group.

The requirements of DUS and of better means and stability of the traits, to be submitted to the plant variety protection application, are given in the L6, L7, L10, L13, L20, and L31 lines.

\section{ACKNOWLEDGMENTS}

We are thankful to FAPERJ and CNPq. In addition, this work was done with the support of the Coordination of Improvement of Higher Education
Personnel, Brazil (CAPES), Financing Code 001.

\section{REFERENCES}

ABREU, FB; LEAL, NR; RODRIGUES, R; AMARAL JÚNIOR, AT; SILVA, DJH. 2004. Divergência genética entre acessos de feijão-de-vagem de hábito de crescimento indeterminado. Horticultura. Brasileira 22: 547-552.

ALMEIDA, SNC; THIEBAUT, JTL; GRAVINA, GA; ARAÚJO, LC; DAHER, RF. 2014. Avaliação de características morfológicas e agronômicas de linhagens de feijão-de-vagem em Bom Jesus do Itabapoana-RJ com potencial de recomendação. Vértices 16: 39-50.

ANDRADE JÚNIOR, AS; SANTOS, AA; SOBRINHOS, CA; BASTOS, EA; MELO, FB; VIANA, FMP; FREITAS FILHO, FR; CARNEIRO, JS; ROCHA, MM; CARDOSO, MJ; SILVA, PHS; RIBEIRO, VQ. 2002. Cultivares e produção de sementes. In: EMBRAPA. Cultivo do Feijão-Caupi (Vigna unguiculata L.). Teresina: Embrapa MeioNorte. $108 \mathrm{p}$.

ARAÚJO, JC. 2010. A lei de proteção de cultivares: análise de sua formação e conteúdo. In: CÂMARA DOS DEPUTADOS. Edições Câmara. Brasília, DF. 137p.

BRASIL. 2015. Ato no. 4 de 13 de julho de 2015. Instruções para execução dos experimentos de distinguibilidade, homogeneidade e estabilidade de cultivares de feijão (Phaseolus vulgaris L.). Diário oficial [da República Federativa do Brasil], Brasília, 15 de julho de 2015, p.2 a 4, seção 1 .

BRITO, R; LOPES, HM; FERNANDES, MCA; AGUIAR, LA; CEARÁ, PS. 2013. Avaliação da qualidade fisiológica e sanitária de sementes de feijão-vagem (Phaseolus vulgaris L.) produzidas sob manejo orgânico e submetidas ao congelamento. Revista Brasileira de Agroecologia 8: 131-140.

CEAGESP. 2015. Normas de classificação da vagem (Phaseolus vulgaris L.). Available at http://www.ceagesp.gov.br/wp-content/ uploads/2015/07/vagem.pdf. Accessed March, 2017.

FILGUEIRA, FAR. 2013. Novo manual de olericultura: agrotecnologia moderna na produção e comercialização de hortaliças. Viçosa: UFV. 421p.

FRANCELINO, FMS; GRAVINA, GA; MANHÃES, CMC; CARDOSO, PMR; ARAÚJO, LC. 2011. Avaliação de linhagens de feijão-de-vagem para as regiões Norte e Noroeste Fluminense. Ciência Agronômica 42: 554-562.

GOMES, GP; BABA, VY; SANTOS, OP; SUDRÉ, CP; Bento, CS; RODRIGUES, R; GONÇALVES, LSA. 2019. Combinations of distance measures and clustering algorithms in pepper germplasm characterization. Horticultura Brasileira 37: 172-179.

MACHADO, RZ. 2011. Elaboração de diretrizes de dintinguibilidade, homogeneidade e estabilidade (DHE). In: Proteção de cultivares no Brasil/Ministério da Agricultura, Pecuária e Abastecimento. Secretaria de Desenvolvimento Agropecuário e Cooperativismo. Brasília: Mapa/ACS. p.121-142.

MOHAMMADI, R; AMRI, A. 2013. Genotype $\mathrm{x}$ environment interaction and genetic improvement for yield and yield stability of rainfed durum wheat in Iran. Euphytica 192: 227-249.

OLIVEIRA, P; ANDRADE, AC; TAVARES SOBRINHO, J; PEIXOTO, N. 2001. Avaliação de linhagens e cultivares de feijão-vagem de crescimento indeterminado, no município de Areia-PB. Horticultura Brasileira 19: 159-162.

OLIVEIRA, TRA; GRAVINA, GA; OLIVEIRA, GHF; ARAÚJO, KC; ARAÚJO, LC; DAHER, RF; VIVAS, M; GRAVINA, LM; CRUZ, DP. 2018. The GT biplot analysis of green bean traits. Ciência Rural 48: 1-6.

PEIXOTO, N; THUNG, MDT; SILVA, LO; FARIAS, JG; OLIVEIRA, EB; BARBEDO, ASC; SANTOS, G. 1997. Avaliação de cultivares arbustivas de feijão-vagem, em diferentes ambientes do Estado de Goiás. In: EMATER-GO. Boletim de Pesquisa 01. Goiânia, p. 20.

PIMENTA, S; RODRIGUES, R; SUDRÉ, CP; MORAES, JGT; BENTO, CS; MEDEIROS, AM. 2016. Protecting vegetable cultivars in Brazil: a chili pepper case-study research. Horticultura Brasileira 34: 161-167.

SANT'ANNA, CQSS. 2019. Análise de Distinguibilidade, Homogeneidade, Estabilidade e GT biplot na proteção de novas linhagens de feijão-de-vagem para $o$ Norte e Noroeste Fluminense. Campos dos Goytacazes: UENF, 77p. (Ph.D. Thesis).

SANTOS, FS; MACHADO, RZ. 2011. Analisando a estabilidade. In: Proteção de cultivares no Brasil. Ministério da Agricultura, Pecuária e Abastecimento. Secretaria de Desenvolvimento Agropecuário e Cooperativismo. Brasília: Mapa/ACS. p.183-185.

SILVA, CQ; JASMIM, JM; SANTOS, JO; BENTO, CS; SUDRÉ, CP; RODRIGUES, R. 2015. Phenotyping and selecting parents for ornamental purposes in pepper accessions. Horticultura Brasileira 33: 66-73.

SILVA, CQ; RODRIGUES, R; BENTO, CS; PIMENTA, S. 2017. Heterosis and combining ability for ornamental chili pepper. Horticultura Brasileira 35: 349-357.

UPOV. 2016. Plants of new varieties of international union for the protection of new varieties of plants. Available at www.upov.int/ en/publications/conventions/1991/act1991. htm. Accessed June, 2016.

VIDAL, VL; JUNQUEIRA, AMR; PEIXOTO, N; MORAES, EA. 2007. Desempenho de feijãovagem arbustivo, sob cultivo orgânico em duas épocas. Horticultura Brasileira 25: 10-14.

WICKHAM, H. 2016. Ggplot2: Elegant Graphics for Data Analysis. New York: Springer. p.258.

YANG, RC; CROSSA, J; BURGUEÑO, J. 2009. Biplot analysis of genotype $\mathrm{x}$ environment interaction: Proceed with caution. Crop Science 49: 1564-1576 